\title{
Pembelajaran Berbasis Masalah Dengan Penerapan Konflik Kognitif Terhadap Keterampilan Berpikir Kritis Matematis Dan Sikap Peserta Didik MTs.Qudwatun Hasanah T.P 2019/2020
}

\author{
Mulia Rasyidi ${ }^{1}$ Asrorul Azizi ${ }^{2}$ \\ Program Studi Pendidikan IPA Institut Pendidikan Nusantara Global \\ Program Studi Pendidikan Guru Pendidikan Anak Usia Dini Institut Pendidikan Nusantara Global \\ Email.mulia.rasyidi@gmail.com,asroruljilid3@gmail.com
}

\begin{abstract}
Abstrak: Keterampilan berpikir kritis matematis, dan sikap positif peserta didik terhadap IPA Terpadu merupakan komponen penting yang harus dimiliki oleh seorang peserta didik, sehingga dengan memiliki keterampilan ini diharapkan membantu peserta didik dalam memecahkan masalah IPA Terpadu, maupun masalah sehari-hari. Salah satu cara mengembangkan keterampilan ini adalah dengan pembelajaran berbasis masalah dengan strategi konflik kognitif merupakan pembelajaran yang berdasarkan masalah, dimana pada masalah yang dikemukakan terdapat fakta, keadaan, situasi yang mempertentangkan struktur kognisi peserta didik. Dalam situasi ini terjadi konflik antara pengetahuan yang dimiliki peserta didik dengan situasi yang sengaja disediakan. Permasalahan utama dalam penelitian ini adalah bagaimana keterampilan berpikir kritis matematis dan sikap peserta didik MTs.Qudwatun Hasanah Mertak Kesambik kelas VIII berdasarkan model pembelajaran, peserta didik, dan level sekolah. Penelitian ini merupakan penelitian eksperimental. Populasi dalam penelitian ini adalah peserta didik MTs.Qudwatun Hasanah Mertak Kesambik kelas VIII di Lombok Tengah. Instrumen yang digunakan pada penelitian ini meliputi tes keterampilan IPA Terpadu, tes keterampilan berpikir kritis matematis, skala sikap peserta didik terhadap IPA Terpadu. Tujuan dari penelitian yang akan dilakukan adalah: mengkaji dan menganalisis perbedaan keterampilan berpikir kritis matematis, sikap peserta didik peserta didik yang menerima pembelajaran berbasis masalah dengan strategi konflik kognitif dan pembelajaran konvensional ditinjau dari: a) keseluruhan, pengetahuan awal peserta didik (tinggi, sedang, dan rendah), dan level sekolah.
\end{abstract}

Kata Kunci: Berpikir Kritis, Berbasis masalah

Abstract: Mathematical critical thinking skills, and positive attitudes of students towards Integrated Science are important components that must be possessed by a student, so having these skills is expected to help students in solving Integrated Science problems, as well as everyday problems. One way to develop these skills is by problem-based learning with cognitive conflict strategies which are problem based learning, where the problems raised include facts, circumstances, situations that conflict with the cognitive structure of students. In this situation there is a conflict between the knowledge possessed by students and the situation that is intentionally provided. The main problem in this study is how the mathematical critical thinking skills and attitudes of students in MTs.Qudwatun Hasanah Mertak Kesambik class VIII based on learning models, students, and school level. This research is an experimental research. The population in this study were students of MTs.Qudwatun Hasanah Mertak Kesambik class VIII in Central Lombok. The instruments used in this study include Integrated Science skills tests, tests of mathematical critical thinking skills, scale of students' attitudes towards Integrated Science. The purpose of the research to be carried out is: to study and analyze differences in mathematical critical thinking skills, the attitude of students who receive problem-based learning with cognitive conflict strategies and conventional learning in terms of: a) overall, students' initial knowledge (high, medium, and low), and school level.

Keywords: Critical Thinking, Problem based 


\section{PENDAHULUAN}

Dari berbagai studi, baik yang berskala internasional maupun nasional menunjukan bahwa kualitas pendidikan di Indonesia masih memprihatinkan. Hal ini dapat dilihat dari Human Development Index (HDI) yang dikeluarkan oleh UNDP. Salah satu indikator dalam menentukan HDI adalah kualitas pendidikan pada suatu negara dari tingkat sekolah dasar sampai menengah. HDI Indonesia hanya sebesar 0,728 dari nilai ideal sebesar satu dan menempatkan Indonesia pada peringkat ke-107 dari 177 negara yang diukur.

Cermin dari pengusaan materi IPA Terpadu peserta didik MTS.Qudwatun Hasanah Mertak Kesambik di Indonesia terlihat dari hasil laporan The Trends International in Mathematics and Science Study (TIMSS) 1999, 2003, dan 2007. Dari hasil kajian TIMSS menunjukkan bahwa peringkat Indonesia masih dari yang diharapkan. Sejalan dengan hasil TIMSS, hasil tes Programme for International Student Assesment (PISA) 2003 dan 2006 yang dikoordinir oleh Organization forEconomic Co-operation and Development (OECD) menunjukkkan hasil yang serupa. Hasil TIMSS dan PISA mengungkapkan bahwa keterampilan matematis peserta didik Indonesia untuk soal-soal tidak rutin dan pemahaman konsep masih sangat lemah, namun relatif baik dalam menyelesaikan soalsoal fakta dan prosedur (Mullis dkk, 2000, 2004, 2008).

Rendahnya hasil belajar IPA Terpadu mengindikasikan ada sesuatu yang salah dan belum optimal dalam pembelajaran IPA Terpadu di sekolah. Hal ini sejalan dengan hasil penelitian yang dilakukan (Sullivan,1992, IMSTEP-JICA, 1999, Sutiarso, 2000, Armanto, 2002 dan Dahlan,2004). Hasil

penelitian mereka mengungkapkan bahwa dalam pembelajaran IPA Terpadu di sekolah peserta didik cendrung pasif, mengutamakan drill dan mekanistik, berpusat pada guru (teacher oriented), chalk and talk. Guru sebagai salah satu pusat dalam proses pembelajaran di kelas masih memandang bahwa belajar adalah suatu proses transfer ilmu pengetahuan (transfer of knowledge) dari pengajar kepada peserta didik.

Menurut teori Piaget, tentang proses perkembangan kognitif mengatakan sturktur kognitif yang kita miliki selalu berinteraksi dengan lingkungannya dengan cara asimilasi dan akomodasi. Jika asimilasi dan akomodasi terjadi secara bebas atau tanpa konflik, maka struktur kognitif dikatakan berada pada keadaan seimbang (equilibrium) dengan lingkungannya. Namun, jika terjadi konflik maka seseorang berada pada keadaan tidak seimbang skema yang masuk tidak sama dengan struktur (skema) kognitif yang dimilikinya. Ketika seorang berada pada keadaan disequilibrium, dia akan merespon keadaan ini, dan berupaya mengingat, memberdayakan konsep yang dimilikinya untuk mencari equilibrium baru dengan lingkungannya. Melalui metakognisi, bertanya pada teman yang tidak mengalami konflik, atau scaffolding yang diberikan guru maka peserta didik dapat keluar dari konflik. Jadi, konflik kognitif merupakan syarat awal atau stimulus dalam memperoleh keseimbangan (equilibrium) baru. Tingkat keseimbangan (equilibrium) baru ini lebih tinggi tingkatannya dari keseimbangan (equilibrium) sebelumnya. Ennis (1996, xx) mengemukakan bahwa berpikir kritis merupakan suatu proses berpikir yang bertujuan agar kita dapat membuat keputusankeputusan yang masuk akal, sehingga apa yang kita anggap terbaik tentang suatu kebenaran dapat kita lakukan dengan benar.

Pembelajaran berbasis masalah merupakan pembelajaran yang menitik beratkan pada kegiatan pemecahan masalah, dan masalah yang harus diselesaikan merupakan masalah yang belum jadi atau tidak terstruktur dengan baik (ill-structured problem), sehingga hal ini dapat menantang peserta didik untuk berpikir dan melakukan diskusi secara berkelompok. Peserta didik dihadapkan pada masalah nyata atau masalah yang disimulasikan, peserta didik bekerjasama secara berkelompok untuk mengembangkan ketrampilan memecahkan masalah (problem solving), kemudian peserta didik 
mendiskusikan apa yang harus dilakukan dan bernegoisasi untuk memba

Berdasarkan uraian latar belakang yang dikemukakan, maka masalah yang dikaji dalam penelitian ini adalah: Apakah terdapat perbedaan keterampilan berpikir kritis matematis dan sikap peserta didik, antara peserta didik yang menerima pembelajaran berbasis masalah dengan strategi konflik kognitif (PBLKK) dan peserta didik yang belajar secara konvensional (KV) ditinjau dari: keseluruhan, pengetahuan awal IPA Terpadu peserta didik (PAM), dan level sekolah?

\section{METODE PENELITAN}

Penelitian ini merupakan penelitian eksperimen karena peneliti bermaksud memberikan perlakuan kepada subjek penelitian untuk selanjutnya ingin mengetahui pengaruh dari perlakuan tersebut. Perlakuan tersebut adalah pembelajaran berbasis masalah dengan strategi konflik kognitif di kelas eksperimen dan pembelajaran konvensional di kelas kontrol. Variabel bebas dalam penelitian ini adalah pendekatan pembelajaran berbasis masalah dengan strategi konflik kognitif (PBLKK) dan pembelajaran konvensional $(\mathrm{KV})$. Kelas yang diajar dengan PBLKK merupakan kelas eksperimen, sedangkan kelas yang diajar dengan pembelajaran konvensional (KV) merupakan kelas kontrol.

Variabel terikat dalam penelitian ini adalah keterampilan berpikir kritis matematis.. Variabel kontrol dalam penelitian ini adalah pengetahuan awal (student prior knowledge) IPA Terpadu peserta didik (PAM). PAM peserta didik adalah pengetahuan IPA Terpadu yang telah dimiliki peserta didik sebelum penelitian ini dilaksanakan. PAM peserta didik ditentukan oleh tes keterampilan awal IPA Terpadu dan nilai rapor IPA Terpadu peserta didik ketika duduk di kelas VII.

Disain eksperimen yang digunakan adalah only postets group disign yang digabung dengan disain 332 , yaitu tiga kelompok PAM peserta didik (tinggi, sedang, dan rendah), tiga level sekolah, dan dua model pembelajaran (PBLKK dan KV). Disain eksperimen yang digunakan pada penelitian ini dapat dinyatakan sebagai berikut:

\section{$\mathrm{X} \mathrm{OO}$}

\section{Subjek Penelitian}

Populasi penelitian ini adalah seluruh peserta didik MTS.Qudwatun Hasanah Mertak Kesambik di Lombok Tengah Sulawesi

Tengah. Sampel penelitian ini sebanyak 200 orang peserta didik, terdiri dari 102 peserta didik yang memperoleh pembelajaran PBLKK (kelas eksperimen) dan 98 peserta didik yang memperoleh pembelajaran KV (kelas kontrol).

\section{Instrumen Penelitian}

Untuk memperoleh data dalam penelitian ini digunakan instrumen tes yang terdiri dari seperangkat soal untuk mengukur dan mengetahui keterampilan awal IPA Terpadu peserta didik, tes keterampilan berpikir kritis matematis, skala sikap dan rapor peserta didik kelas VII.

\section{Teknik Analisis Data}

Dari penelitian yang dilakukan maka diperoleh data kuantitatif. Data kuantitatif didapat melalui tes keterampilan berpikir kritis dan skala sikap peserta didik. Setelah data diperoleh, kemudian dianalisis untuk didiskripsikan dan diberikan tafsiran-tafsiran. Pengolahan data kuantitatif dilakukan melalui dua tahapan utama.

1. Tahap pertama: menguji persyaratan statistik yang diperlukan sebagai dasar dalam pengujian hipotesis, yaitu uji normalitas sebaran data subyek sampel dan uji homogenitas varians.

2. Tahap kedua: menguji ada atau tidak adanya perbedaan dari masing-masing kelompok dengan menggunakan Uji-t, ANAVA satu jalur dengan bantuan perangkat lunak SPSS-17 for Windows.

\section{Hasil dan Temuan}

Pengetahuan awal IPA Terpadu (PAM) peserta didik adalah pengetahuan yang dimiliki peserta didik sebelum proses pembelajaran berlangsung. Pengetahuan awal IPA Terpadu merupakan rata-rata dari nilai tes keterampilan IPA Terpadu, nilai rapor IPA Terpadu peserta didik pada semester I dan II di kelas VII MTs.Qudwatun Hasanah Mertak Kesambik.

Untuk mengetahui kesetaraan sampel penelitian, telah dilakukan analisis statistik uji perbedaan rata-rata dari skor pengetahuan awal IPA Terpadu. Sebelum dilakukan uji perbedaan rata-rata, terlebih dahulu dilakukan 
uji normalitas dan homogenitas varians data, dan didapat kesimpulan bahwa sampel berasal dari populasi yang berdistribusi normal.

\section{Keterampilan Berpikir Kritis Matematis Peserta didik ditinjau secara Keseluruhan} Hipotesis yang diuji adalah:

$\mathrm{H}_{0}$ : Tidak terdapat perbedaan keterampilan berpikir kritis matematis peserta didik antarayang memperoleh pembelajaran PBLKK pembelajaran KV

$\mathrm{H}_{\mathrm{a}}$ : Terdapat perbedaan keterampilan berpikir kritis matematis peserta didik antarayang memperoleh

pembelajaran PBLKK dan pembelajaran $\mathrm{KV}$.

Kriteria pengujian yang digunakan adalah jika nilai sig. lebih besar dari 0,05, maka hipotesis nol $\left(\mathrm{H}_{0}\right)$ diterima. Sebelum hipotesis diuji, diuji normalitas dan homogenitas varians data dari keterampilan berpikir kritis matematis berdasarkan pada pembelajaran PBLKK dan KV. Dari Hasil perhitungan uji normalitas keterampilan berpikir kritis matematis dapat disimpulkan bahwa data keterampilan berpikir kritis matematis berdistribusi normal. Hasil perhitungan uji-t keterampilan berpikir kritis berdasarkan pembelajaran PBLKK dan KV disajikan pada Tabel 1.

\section{Tabel 1.Uji -t Keterampilan berpikir Kritis Matematis berdasarkan Pembelajaran}

\begin{tabular}{|c|c|c|c|c|}
\hline Keterampilan & $\mathrm{t}$ & $\mathrm{dk}$ & $\begin{array}{c}\text { sig.(2- } \\
\text { tailed })\end{array}$ & $\mathrm{H}_{0}$ \\
\hline Kritis & $\begin{array}{c}2,22 \\
1\end{array}$ & 198 & 0,000 & Tolak \\
\hline
\end{tabular}

Pada Tabel 1 terlihat bahwa nilai sig. keterampilan berpikir matematis lebih kecil dari 0,05. Ini berarti hipotesis nol ditolak. Dengan demikian, terdapat perbedaan yang signifikan keterampilan berpikir kritis matematis peserta didik antara yang memperoleh pembelajaran PBLKK dan pembelajaran KV. Dari data nilai rata-rata juga terlihat bahwa keterampilan berpikir kritis matematis peserta didik yang diajar dengan pembelajaran PBLKK lebih tinggi dibandingkan keterampilan berpikir kritis peserta didik yang diajar dengan pembelajaran konvensional. Jadi keterampilan berpikir kritis matematis peserta didik yang memperoleh pembelajaran PBLKK lebih baik daripada peserta didik yang memperoleh pembelajaran $\mathrm{KV}$.

\section{Keterampilan Berpikir Kritis berdasarkan PAM \\ Hipotesis yang diuji adalah:}

$\begin{aligned} \mathrm{H}_{0}: & \text { Tidak terdapat perbedaan } \\ & \text { keterampilan } \begin{array}{c}\text { berpikir } \\ \text { peserta }\end{array} \\ & \text { matematis } \quad \text { didik } \\ & \text { memperoleh pembelajaran PBLKK } \\ & \text { berdasarkan pengetahuan awal } \\ & \text { IPA Terpadu (PAM) peserta } \\ & \text { didik. }\end{aligned}$

$\mathrm{H}_{\mathrm{a}}$ :Terdapat perbedaan keterampilan peserta berpikir kritis matematis didik setelah memperoleh pembelajaran PBLKK berdasarkan pengetahuan awal IPA Terpadu (PAM) peserta didik.

Kriteria pengujian adalah jika nilai sig. lebih kecil dari 0,05, maka hipotesis nol diterima.

Distribusi keterampilan berpikir kritis matematis peserta didik berdasarkan pengetahuan awal IPA Terpadu (PAM) peserta didik dapat dilihat pada Tabel 2.

Tabel 2. Distribusi Keterampilan Berpikir Kritis Matematis berdasarkan PAM Peserta didik

\begin{tabular}{|c|c|c|c|}
\hline PAM & $\mathrm{n}$ & Rata-rata & $\begin{array}{c}\text { Simpangan } \\
\text { Baku }\end{array}$ \\
\hline Tinggi & 4 & 92,5000 & 6,45497 \\
\hline Sedang & 65 & 71,6923 & 10,46859 \\
\hline Rendah & 33 & 61,5152 & 11,55725 \\
\hline
\end{tabular}

Untuk melihat apakah ada perbedaan keterampilan kritis matematis berdasarkan pengetahuan awal IPA Terpadu (PAM) peserta didik pada peserta didik yang memperoleh PBLKK maka dilakukanlah uji ANAVA satu jalur. Kriteria pengujian adalah 
jika nilai sig. lebih kecil dari $\alpha=0,05$, maka hipotesis nol ditolak.

Hasil perhitungan uji ANAVA satu jalur keterampilan berpikir kritis matematis berdasarkan PAM pada peserta didik yang memperoleh pembelajaran PBLKK disajikan pada Tabel 3

\begin{tabular}{|c|c|c|c|c|c|}
\hline \multicolumn{7}{|c|}{ Tabel 3. Uji ANAVA Keterampilan } \\
Berpikir Kritis Terhadap PAM Peserta \\
didik
\end{tabular}

Pada Tabel 3 terlihat bahwa nilai sig. keterampilan berpikir kritis matematis berdasarkan pengetahuan awal IPA Terpadu (PAM) peserta didik lebih kecil dari 0,05. Ini berarti hipotesis nol ditolak. Dengan demikian, terdapat perbedaan keterampilan berpikir kritis matematis peserta didik berdasarkan pengetahuan awal IPA Terpadu (PAM) peserta didik pada peserta didik yang memperoleh pembelajaran PBLKK. Untuk melihat pada PAM peserta didik mana saja yang berbeda maka dilakukan uji Scheffe.

Berdasarkan hasil uji Scheffe, perbedaan keterampilan berpikir kritis matematis peserta didik terjadi untuk PAM peserta didik sedang dengan PAM peserta didik sedang sebesar 20,81, PAM peserta didik tinggi dan rendah sebesar 30,95, dan PAM sedang dengan PAM rendah sebesar 10,17

\section{Keterampilan Berpikir Kritis berdasarkan Level Sekolah}

Distribusi keterampilan berpikir kritis matematis peserta didik yang memperoleh pembelajaran PBLKK berdasarkan level sekolah dapat dilihat pada Tabel 4.

\section{Tabel 4.Distribusi Keterampilan Berpikir Kritis Matematis berdasarkan Level Sekolah}

\begin{tabular}{|c|c|c|c|}
\hline $\begin{array}{c}\text { Level } \\
\text { Sekolah }\end{array}$ & $\boldsymbol{n}$ & $\begin{array}{c}\text { Rata- } \\
\text { rata }\end{array}$ & $\begin{array}{c}\text { Simpangan } \\
\text { Baku }\end{array}$ \\
\hline Tinggi & 34 & 75,5882 & 12,29466 \\
\hline
\end{tabular}

\begin{tabular}{|c|l|l|l|}
\hline Sedang & 37 & 65,1351 & 12,10409 \\
\hline Rendah & 31 & 67,0968 & 10,86080 \\
\hline
\end{tabular}

Dari Tabel 4 terlihat bahwa rata-rata keterampilan berpikir kritis matematis dari peserta didik yang memperoleh pembelajaran PBLKK pada level sekolah tinggi lebih tinggi dari rata-rata peserta didik dari level sekolah sedang dan level sekolah rendah. Rata-rata keterampilan berpikir kritis matematis dari level sekolah rendah lebih tinggi dari rata-rata peserta didik dari level sekolah sedang. Hipotesis yang diuji adalah:

$\mathrm{H}_{0}$ : Tidak terdapat perbedaan keterampilan berpikir kritis matematis peserta didik yang memperoleh PBLKK berdasarkan level sekolah.

$\begin{array}{rlr}\mathrm{H}_{\mathrm{a}} & \text { : Terdapat perbedaan } \\ & \text { keterampilan berpikir } & \text { kritis } \\ \text { matematis peserta didik yang } & \text { memperoleh } & \text { PBLKK } \\ & \text { berdasarkan level sekolah. }\end{array}$

Kriteria pengujian adalah jika nilai sig. lebih kecil dari $\square=0,05$, maka hipotesis nol diterima. Dari hasil uji Levene dapat disimpulkan bahwa varians data keterampilan berpikir kritis matematis berdasarkan level sekolah adalah homogen.

Untuk melihat ada tidaknya perbedaan keterampilan kritis matematis pada peserta didik yang memperoleh pembelajaran PBLKK berdasarkan level sekolah digunakan uji ANAVA satu jalur. Hasil perhitungan uji ANAVAsatu jalur keterampilan berpikir kritis matematis disajikan pada 
Tabel 5. Uji ANAVA Keterampilan Berpikir Kritis berdasarkan Level Sekolah

\begin{tabular}{|c|c|c|c|c|c|}
\hline & $\begin{array}{c}\text { Jumlah } \\
\text { Kuadrat }\end{array}$ & $\mathrm{dk}$ & $\begin{array}{c}\text { Kuadrat } \\
\text { rata-rata }\end{array}$ & $\mathrm{F}$ & Sig. \\
\hline $\begin{array}{c}\text { Antar } \\
\text { Klpk }\end{array}$ & 2135,986 & 2 & 1067,993 & 7,661 & 0,001 \\
\hline $\begin{array}{c}\text { Dalam } \\
\text { Klpk }\end{array}$ & 13801,269 & 99 & 139,407 & & \\
\hline Total & 15937,255 & 101 & & & \\
\hline
\end{tabular}

Pada Tabel 5. terlihat bahwa nilai sig. keterampilan berpikir kritis matematis peserta didik yang memperoleh pembelajaran PBLKK berdasarkan level sekolah lebih kecil dari 0,05. Ini berarti hipotesis nol ditolak. Dengan demikian, terdapat perbedaan keterampilan berpikir kritis matematis peserta didik yang memperoleh pembelajaran PBLKK berdasarkan level sekolah. Untuk melihat pada level sekolah mana saja yang berbeda maka dilakukan uji Scheffe. Hasil uji Scheffe menunjukkan bahwa keterampilan berpikir kritis matematis berbeda berdasarkan level sekolah. Keterampilan berpikir kritis matematis yang berbeda adalah untuk level sekolah tinggi dengan level sekolah sedang sebesar 10,45, dan level sekolah tinggi dengan level sekolah rendah sebesar 8,49, sedangkan untuk level sekolah sedang dengan level sekolah rendah tidak berbeda.

Sikap Peserta didik terhadap IPA Terpadu

Hipotesis yang diuji adalah:

$\mathrm{H}_{0}$ : Tidak terdapat perbedaan sikap peserta didik terhadap IPA Terpadu antara yang memperoleh pembelajaran PBLKK dan pembelajaran $\mathrm{KV}$

$\mathrm{H}_{\mathrm{a}}$ : Terdapat perbedaan sikap peserta didik terhadap IPA Terpadu antara yang memperoleh pembelajaran PBLKK dan pembelajaran KV.

Kriteria pengujian adalah jika nilai sig. lebih besar dari 0,05, maka hipotesis nol diterima.
Untuk melihat apakah ada perbedaan sikap peserta didik berdasarkan pembelajaran maka digunakan uji-t.

Hasil perhitungan uji-t sikap peserta didik berdasarkan pembelajaran PBLKK, dan KV disajikan pada Tabel 6.

Tabel 6. Uji -t Sikap Peserta didik
Berdasarkan Pembelajaran

\begin{tabular}{|c|c|c|c|c|}
\hline & $\mathbf{t}$ & $\mathbf{d k}$ & $\begin{array}{c}\text { sig.(2- } \\
\text { tailed) }\end{array}$ & $\mathbf{H}_{\mathbf{0}}$ \\
\hline Sikap & 3,740 & 198 & 0,000 & Tolak \\
\hline
\end{tabular}

Pada Tabel 6 terlihat bahwa nilai sig. sikap peserta didik lebih kecil dari 0,05, ini berarti hipotesis nol ditolak. Dengan demikian, dapat disimpulkan bahwa terdapat perbedaan sikap peserta didik antara yang memperoleh pembelajaran PBLKK dan pembelajaran KV. Artinya, sikap peserta didik yang diajar dengan pembelajaran PBLKK lebih positif dibandingkan dengan sikap peserta didik yang diajar dengan pembelajaran konvensional.

Distribusi sikap peserta didik berdasarkan level sekolah dapat dilihat pada Tabel 7.

Tabel 7.Distribusi Sikap Peserta didik berdasarkan Level Sekolah

\begin{tabular}{|c|c|c|c|}
\hline $\begin{array}{c}\text { Level } \\
\text { Skolah }\end{array}$ & $\boldsymbol{n}$ & Rata-rata & $\begin{array}{c}\text { Simpangan } \\
\text { Baku }\end{array}$ \\
\hline Tinggi & 34 & 105,9706 & 10,91700 \\
\hline Sedang & 37 & 109,2432 & 7,93167 \\
\hline Rendah & 31 & 109,9677 & 11,77705 \\
\hline
\end{tabular}

Dari Tabel 7 terlihat bahwa rata-rata sikap peserta didik level sekolah tinggi lebih rendah dari rata-rata sikap peserta didik level sekolah sedang dan rata-rata sikap level sekolah rendah. Rata-rata sikap peserta didik level sekolah rendah relatif lebih baik dari rata-rata sikap peserta didik level sekolah sedang. Untuk melihat ada tidaknya perbedaan skala sikap peserta didik yang memperoleh PBLKK berdasarkan level sekolah digunakan uji ANAVA satu jalur. Hasil perhitungan uji ANAVA satu jalur 
skala sikap peserta didik yang memperoleh PBLKK menunjukkan bahwa nilai sig.adalah 0,240 lebih besar dari 0,05. Ini berarti hipotesis nol diterima. Dengan demikian, tidak terdapat perbedaan sikap peserta didik terhadap IPA Terpadu yang memperoleh pembelajaran PBLKK berdasarkan level sekolah. Hal ini juga didukung oleh uji Scheffe yang menunjukkan bahwa semua nilai sig. untuk setiap level sekolah lebih besar dari 0,05. Sehingga dapat disimpulkan sikap peserta didik yang memperoleh PBLKK tidak berbeda berdasarkan level sekolah. Jadi pada setiap level sekolah sikap peserta didik adalah sama.

Perbandingan rata-rata keterampilan berpikir kritis matematis berdasarkan level sekolah disajikan pada Diagram 1.

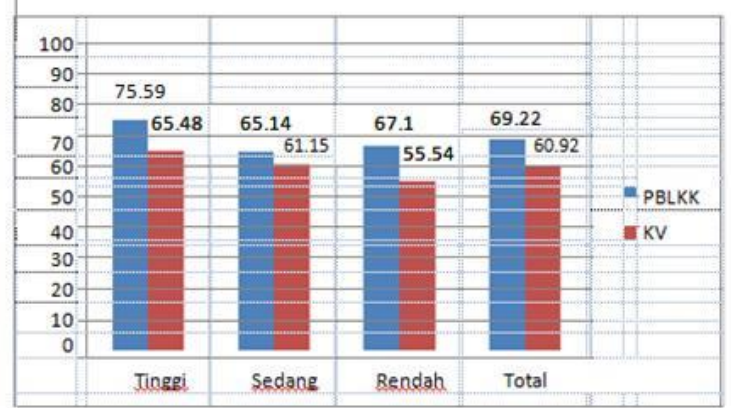

Diagram.1

Rata-rata Keterampilan Berpikir Kritis Matematis berdasarkan Level Sekolah

Rata-rata keterampilan berpikir kritis matematis peserta didik pada level sekolah tinggi $=75,59$, sedang $=65,14$, dan rendah $=$ 67,10 yang memperoleh pembelajaran PBLKK masih lebih tinggi dari rata-rata keterampilan berpikir kritis matematis peserta didik pada level sekolah tinggi $=65,48$, sedang 61,152, dan rendah $=55,54$ dengan pembelajaran $\mathrm{KV}$. Jadi pada setiap level sekolah rata-rata keterampilan berpikir kritis peserta didik yang memperoleh pembelajaran PBLKK lebih tinggi daripada peserta didik yang memperoleh pembelajaran konvensional. Perbandingan keterampilan berpikir kritis matematis berdasarkan PAM peserta didik dapat dilihat pada Diagram 2. Dari Diagram 2 terlihat bahwa berdasarkan PAM peserta didik, maka keterampilan berpikir kritis peserta didik yang memperoleh pembelajaran PBLKK masih lebih baik dari peserta didik yang memperoleh pembelajaran konvensional.

Perbandingan rata-rata keterampilan berpikir kritis matematis berdasarkan PAM peserta didik disajikan pada diagram 2 .

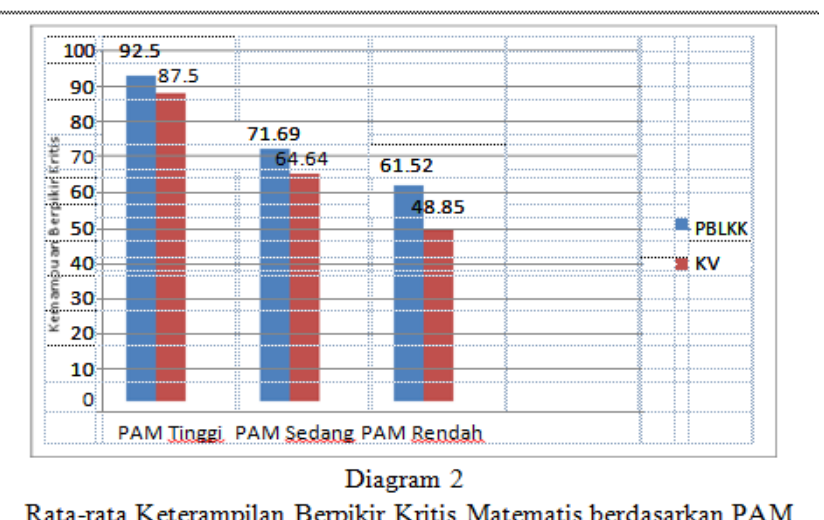

Keterampilan kritis matematis peserta didik yang memperoleh pembelajaran PBLKK dengan PAM tinggi $=92,50$, sedang $=71,69$ dan rendah $=61,52$. Rata-rata ini masih lebih tinggi dari rata-rata keterampilan kritis matematis peserta didik yang memperoleh pembelajaran $\mathrm{KV}$ dengan $\mathrm{PAM}$ tinggi $=$ 87,500 , sedang $=64,64$ dan rendah $=48,85$. Jadi peserta didik yang memperoleh pembelajaran PBLKK lebih tinggi dari peserta didik yang memperoleh pembelajaran konvensional berdasarkan PAM peserta didik.

\section{Kesimpulan}

1. Keterampilan berpikir kritis matematis peserta didik yang memperoleh pembelajaran PBLKK lebih baik daripada peserta didik yang memperoleh pembelajaran KV.

2. Keterampilan berpikir kritis matematis peserta didik yang memperoleh pembelajaran BPLKK berbeda berdasarkan pengetahuan awal IPA Terpadu (PAM) peserta didik, yaitu untuk PAM peserta didik tinggi dengan PAM peserta didik sedang, PAM peserta didik tinggi dengan PAM peserta didik rendah, dan untuk PAM peserta didik sedang dengan PAM peserta didik rendah.

3. Keterampilan berpikir kritis matematis yang memperoleh pembelajaran PBLKK berbeda menurut level sekolah. Perbedaan keterampilan berpikir kritis adalah untuk level sekolah tinggi dengan level sekolah sedang, dan level sekolah tinggi dengan 
level sekolah rendah, sedangkan untuk level sekolah sedang dengan level sekolah rendah tidak berbeda.

4. Sikap peserta didik yang diajar dengan pembelajaran PBLKK lebih positif dibandingkan dengan sikap peserta didik yang diajar dengan pembelajaran konvensional

\section{DAFTAR PUSTAKA}

Armanto, D. (2001) Upaya Peningkatan

Pembelajaran IPA Terpadu SD

Melalui Pendidikan IPA Terpadu

Realistik (PMR).Seminar

Nasional Pendidikan IPA Terpadu

Baron, J. B and Sternberg, R. J. (1987).

Teaching Thinking Skills : Theory and

Practice, New York : W. H. Freeman and Company.

Dahlan, J.A.(2004). Meningkatkan

Keterampilan penalaran dan Pemahaman Peserta didik SLTP Melalui Pendekatan Pembelajaran Open-Ended. Bandung: Disertasi SPS UPI tidak diterbitkan.

Delishe, R. (1997). How to Use Problem-

Based Learning in The Classroom. New York. ASCD.

Ennis, R. H, (1996). Critical Thinking, United States of America: Prentice-Hall Inc.

Fisher, R. (1995). Thinking Children to Think, Cheltenham, United Kingdom : Stanley Thornes Ltd

Fogarty, R. (1997). Problem-Based

Learning and the Other Curriculum Models for Multiple Intelegences Classroom. Hawker Brownlow Education.

Gijselaers, W.H.(1996). Connecting Problem-Based Practice with

Educational Theory. Dalam Wilkerson, L.(Ed). New Direction for Theaching and Learning. No.68. Josey-Bass Publisher.

IMSTEP-JICA (1999). Permasalahan Pembelajaran IPA Terpadu SD,
SLTP, dan SMU di Kota Bandung: Bandung: FMIPA UPI.

Krulik, S. (1980), Problem Solving in School Mathematics. NCTM.

Marzano, R. J et.al. (1989). Dimention of Thingking : A Framework for Curricullum and Instruction. Alexanderia US : Association for Supervision and Curriculum Development

Ngeow, K.K. dan San, Y. (1997). Learning to learn: Preparing Teachers and Student for 